\title{
Development of the bovine placentome from Days 20 to 29 of gestation
}

\author{
G. J. King, B. A. Atkinson and H. A. Robertson* \\ Department of Animal \& Poultry Science, University of Guelph, Guelph, Ontario, Canada N1G \\ 2W1, and *Animal Research Institute, Ottawa, Canada K1 A OC6
}

\begin{abstract}
Summary. Nulliparous heifers $(\mathrm{N}=21)$ were killed at each day between Days 20 and 29 after insemination. Placentomes were collected from the region near the embryo and prepared for examination by light electron microscopy. At Day 20 placentomes could be recognized as discrete oval structures on the surface of the uterine lumen. At Day 20-21, the trophoblast was in close apposition to the caruncular epithelium with microvilli from the maternal cells indenting the apical border of the embryonic cells. Mutual interdigitation of microvilli was present by Day 24 and this progressed to intimate attachment by Day 27 . In the early stages, the maternal cell types ranged from tall columnar to very thin, elongated cells with some excessively large multinucleate cells, but became uniformly cuboidal by Day 29. Trophoblast giant cells, without microvilli, were observed in contact with the maternal epithelium at all stages examined.
\end{abstract}

\section{Introduction}

The progressive stages of apposition, adhesion and attachment of the bovine chorion were studied by Leiser (1975) who observed adhesion in the intercaruncular region near the embryo by Day 22. Attachment subsequently spread and, by Day 27, was observed over the uterine mucosa with the exception of the caruncles and small residual areas, indicating that development of the placenta was dependent upon the location in relation to the embryo as well as the day of gestation. Leiser (1975) implied that actual contact on the surface of the caruncle did not commence until about Day 30 of gestation, but King, Atkinson \& Robertson (1979) have described the definite formation of placentomes by this time. The present study examined the development of the bovine placentome between Days 20 and 29. Tissue was collected from the immediate vicinity of the embryo to reduce the variation inherent in more widespread sampling.

\section{Materials and Methods}

Nulliparous heifers of mixed breeding were inseminated on the day of oestrus (Day 0). One animal was slaughtered at Day 20 and groups of 2-4 on each day between Days 21 and 29 after insemination. The reproductive tract was removed immediately after exsanguination. In most animals the gravid horn was perfused with $2 \%(\mathrm{w} / \mathrm{v})$ paraformaldehyde plus $0.07 \%(\mathrm{w} / \mathrm{v})$ picric acid in cacodylate buffer $(0.2 \mathrm{M}, \mathrm{pH} 7.4)$ by means of a blunted, 18-gauge needle inserted into the middle uterine artery. In all specimens, a small cut was then made through the uterine wall near the mid-point of the horn to expose the uterine epithelium/chorion. A 21-22-gauge needle was introduced through this cut, into the lumen, in an attempt to introduce the fixative into the 
allantoic cavity. The trimmed horn was then immersed in a solution of $6 \%(\mathrm{w} / \mathrm{v})$ paraformaldehyde plus $0.2 \%(\mathrm{w} / \mathrm{v})$ picric acid in cacodylate buffer $(0.2 \mathrm{M}, \mathrm{pH} 7.4)$ for $20 \mathrm{~min}$, opened along the mesometrial surface and fixed for an additional $10 \mathrm{~min}$. After the initial fixation and hardening, entire placentomes were removed from the gravid horn within $3 \mathrm{~cm}$ of the embryo or from the middle of the horn if the embryo had been dislodged. These samples were placed into a fixative mixture containing $2 \%(\mathrm{v} / \mathrm{v})$ glutaraldehyde, $1 \%(\mathrm{w} / \mathrm{v})$ paraformaldehyde and $0.01 \%(\mathrm{w} / \mathrm{v})$ trinitroresorcinol in cacodylate buffer $(0.2 \mathrm{M}, \mathrm{pH} 7.4)$ for $2 \mathrm{~h}$. A portion of each placentome was then placed in Bouin's fluid for an additional 24-48 h. These specimens were subsequently dehydrated, embedded in paraffin wax, sectioned at $5 \mu \mathrm{m}$ and stained with haematoxylin and eosin for light microscopy.

The remaining portion of each placentome was further processed by trimming into $1 \mathrm{~mm}$ cubes after the initial $2 \mathrm{~h}$ fixation. These small blocks were left in the glutaraldehyde fixative for a further $1.5 \mathrm{~h}$, washed, post-fixed in $1 \%(\mathrm{w} / \mathrm{v})$ osmium tetroxide in cacodylate buffer $(0.2 \mathrm{M}, \mathrm{pH}$ 7.4) containing $0.3 \mathrm{M}$ glucose, block-stained for $2 \mathrm{~h}$ at room temperature in a $5 \%(\mathrm{w} / \mathrm{v})$ solution of uranyl acetate in distilled water which had been filtered immediately before use, dehydrated in a graded series of alcohols and embedded in Spurr's resin (Spurr, 1969). Thick sections (1 $\mu \mathrm{m})$ were mounted on glass slides and stained with Paragon $(0.73 \%(\mathrm{w} / \mathrm{v})$ toluidine blue plus $0.272 \%(\mathrm{w} / \mathrm{v})$ basic fuchsin in $30 \%(\mathrm{v} / \mathrm{v})$ ethyl alcohol), following the procedure described by King et al. (1979). Thin sections were cut from blocks that showed suitable areas, stained with lead citrate and examined with an electron microscope.

The subcellular components of epithelial cells were described as apical or basal according to their proximity to the epithelial basal lamina.

\section{Results}

\section{Placentomes}

The placentomes at all stages could be identified on the surface of the uterine lumen as discrete oval structures. In unperfused specimens, the placentomes were lighter in colour than the surrounding intercaruncular areas, but this difference was reduced by perfusion. The caruncular surfaces were smooth, with no evidence of undulations or crypt development at all stages between Days 20 and 29. The general outline of the caruncle was regularly convex in most specimens, but some had slight depressions at the centre (Pl. 1, Fig. 1). Apposition between the trophoblast and the caruncle was difficult to preserve in specimens embedded in paraffin wax but, wherever the trophoblast was present, it followed the general outline of the caruncle. Observations on plastic-embedded tissue revealed that apposition with tenuous adhesion or definite attachment were present at all stages examined.

\section{Maternal component}

The general appearance of the maternal epithelium was quite variable in the early stages but developed into a moderately regular, cuboidal form by Day 27 (Pl. 8, Fig. 15). At 20 and 21 days, cell types ranged from tall columnar (Pl. 2, Fig. 3) to very thin, elongated cells (Pl. 1, Fig. 2). The most common multinuclear cells, present at all stages, were binucleate giant cells which were quite large in early specimens, with abundant cytoplasm and dispersed nuclei (Pl. 2, Fig. 3). As gestation progressed, the ratio of cytoplasm to nuclei was reduced until the multinuclear cells were only slightly larger than the cuboidal, mononuclear cells making up the remainder of the epithelial layer (Pl. 2, Fig. 4). The giant cells observed during this early stage of gestation had more cytoplasm and a different nuclear configuration than the typical uterine giant cells observed after Day 30 (Björkman, 1968; King et al., 1979). 
Occasionally, very large cells with large numbers of randomly arranged nuclei were present as late as Day 28 (Pl. 4, Figs. 6 and 7; Pl. 5, Fig. 8). Some of these polynuclear cells were extensive in all dimensions while others were long and thin. The latter were infrequently observed up to Day 25, and possibly represented a maternal syncytium (Pl. 3, Fig. 5). The apical borders of the bi- or multi-nucleate cells were covered with microvilli (Pl. 4, Fig. 7). Higher resolution revealed that these microvilli interdigitated with the adjacent trophoblast cells. This agreed with previous descriptions (Björkman, 1968; Leiser, 1975) and indicated that these cells were part of the maternal epithelium, although the origin and mode of formation of such cells has never been demonstrated.

Lipid vesicles were almost totally absent in the early stages but their number increased as gestation progressed. Individual cells undergoing obvious degeneration were present in the maternal epithelium throughout the period under study (Pl. 2, Fig. 3; Pl. 4, Fig. 6; Pl. 6, Fig. 10). Several sections, when examined with the light microscope, revealed areas in which the trophoblast appeared to touch the maternal connective tissue. In almost all cases, when serial sections were examined by electron microscopy, an intact maternal basal lamina and thin processes of maternal epithelial cytoplasm could be detected separating the trophoblast cells from the maternal connective tissue. However, in sections from one caruncle, at 25 days, the matrix between the trophoblast cells and the maternal connective tissue was indistinct and no true basal lamina could be identified in one area (Pl. 6, Figs 10 and 11). A more critical examination employing a goniometer stage might resolve this questionable specimen.

The basal lamina was quite straight in the earliest specimens (Pl. 1, Fig. 2; Pl. 2, Fig. 3), became undulating by Day 27 (Pl. 4, Fig. 6) and was scalloped by Day 29 (Pl. 2, Fig. 4). The endometrial connective tissue up to 27 days showed a uniform intensity of staining in all plastic sections (Pl. 2, Fig. 3; Pl. 5, Fig. 8; Pl. 6, Fig. 10). All sections from animals killed after Day 26 revealed a band of less intensively stained connective tissue immediately below the basal lamina. The nuclei of cells in this band were larger, lighter and more regular in outline than the nuclei in the underlying fibroblasts (Pl. 4, Fig. 6; Pl. 2, Fig. 4).

\section{Endometrial-trophoblast interface}

Close apposition was preserved between the trophoblast and the maternal epithelium in some specimens from all experimental animals. Whenever a lengthy separation was detected in plastic-embedded material, it was in the maternal epithelium or the trophoblast, rather than at the interface. Occasionally, small areas of non-apposition were observed but these were invariably flanked by regions of close apposition and were probably artefactual (Pl. 5, Fig. 8). In 20-day specimens, there were some areas where maternal microvilli were indenting the apical borders of the adjacent trophoblast cells (Pl. 7, Fig. 12). Mutual interdigitation of microvilli was present by Day 24 and this progressed to intimate attachment by Day 27 (Pl. 7, Fig. 13).

\section{Trophoblast}

The most dramatic change in the appearance of the trophoblast was the increased accumulation of lipid material which became concentrated in the basal region of the mononuclear cells as gestation progressed. A few lipid drops were observed in the early stages (Pl. 1, Fig. 2; Pl. 2, Fig. 3; Pl. 6, Fig. 10). By Day 27, considerably more lipid material was present (Pl. 4, Fig. 6) and extensive accumulations were observed by Day 29 (PI. 2, Fig. 4). Lipid material was concentrated in regions of the trophoblast that were sparsely populated by giant cells. Vesicles of all sizes were common and some of these contained degenerating material (Pl. 4, Fig. 6). 


\section{PLATES $1-8$}

Abbreviations: BL, basal lamina; BV, blood vessel; C, chorion; CAR, caruncle; DC, degenerating cell; FE, trophoblast epithelial cell; FG, trophoblast giant cell; L, vesicle containing degenerating material; ld, lipid drop; lp, lipid droplets; $m$, mitochondria; $M E$, uterine epithelial cell; MF, uterine fibroblast; MG, uterine giant cell; mv, microvilli; $p$, polysomes.

\section{PLATE 1}

Fig. 1. Placentome at 21 days after insemination. Bouin, $5 \mu \mathrm{m}, \mathrm{H} \& \mathrm{E}$.

Fig. 2. The relationship between the trophoblast and thin maternal epithelium at Day 21 , showing contact between a trophoblast giant cell and the maternal epithelium, plus the relatively straight basal lamina.

\section{PLATE 2}

Fig. 3. The superficial layers of a placentome illustrating a degenerating cell and the variation in cell heights and types observed in the maternal epithelium in the early stages (Day 20). $1 \mu \mathrm{m}$, Paragon.

Fig. 4. The superficial layers of the placentome at Day 29 with the typical, cuboidal, maternal epithelium, scalloped basal lamina, light band in the underlying connective tissue and the increased lipid content of trophoblast and maternal epithelial cells. $1 \mu \mathrm{m}$, Paragon.

\section{PLATE 3}

Fig. 5. Electron micrograph montage showing a portion of an elongated, multinuclear, maternal epithelial cell (Day 21).

\section{PLATE 4}

Fig. 6. The superficial layers of a placentome at Day 27 illustrating one multinucleated and two degenerating cells in the maternal epithelium. The undulating basal lamina and light band in the connective tissue are present. Vesicles containing degenerating material are located in the trophoblast. $1 \mu \mathrm{m}$, Paragon.

Fig. 7 Enlargement of the maternal giant cell near the right edge of Fig. 6, demonstrating prominent microvillous process̀es.

\section{PLATE 5}

Fig. 8. Multinuclear maternal giant cell contacting a trinucleate trophoblast giant cell (Day 25). $1 \mu \mathrm{m}$, Paragon.

Fig. 9. The contact region between a trophoblast giant cell and the maternal epithelium (Day 27). Note the absence of microvilli.

\section{PLATE 6}

Fig. 10. The superficial layers of a placentome with the maternal epithelium present at both edges but apparently absent in the central area (Day 25). $1 \mu \mathrm{m}$, Paragon.

Fig. 11. The apical region of the trophoblast giant cell (FG in Fig. 10) and an adjacent, endometrial fibroblast. No maternal epithelium or basal lamina could be resolved at this point.

\section{PLATE 7}

Fig. 12. The endometrial-trophoblast interface showing maternal microvilli indenting the apical border of a trophoblast cell (Day 20).

Fig. 13. The endometrial-trophoblast interface with mutual interdigitation of microvilli (Day 27).

\section{PLATE 8}

Fig. 14. Trophoblast giant cell with no evidence of secretory vesicles (Day 21).

Fig. 15. A maternal epithelial cell showing the typical organelles and cuboidal shape that were common at this and later stages (Day 27). 
PLATE I
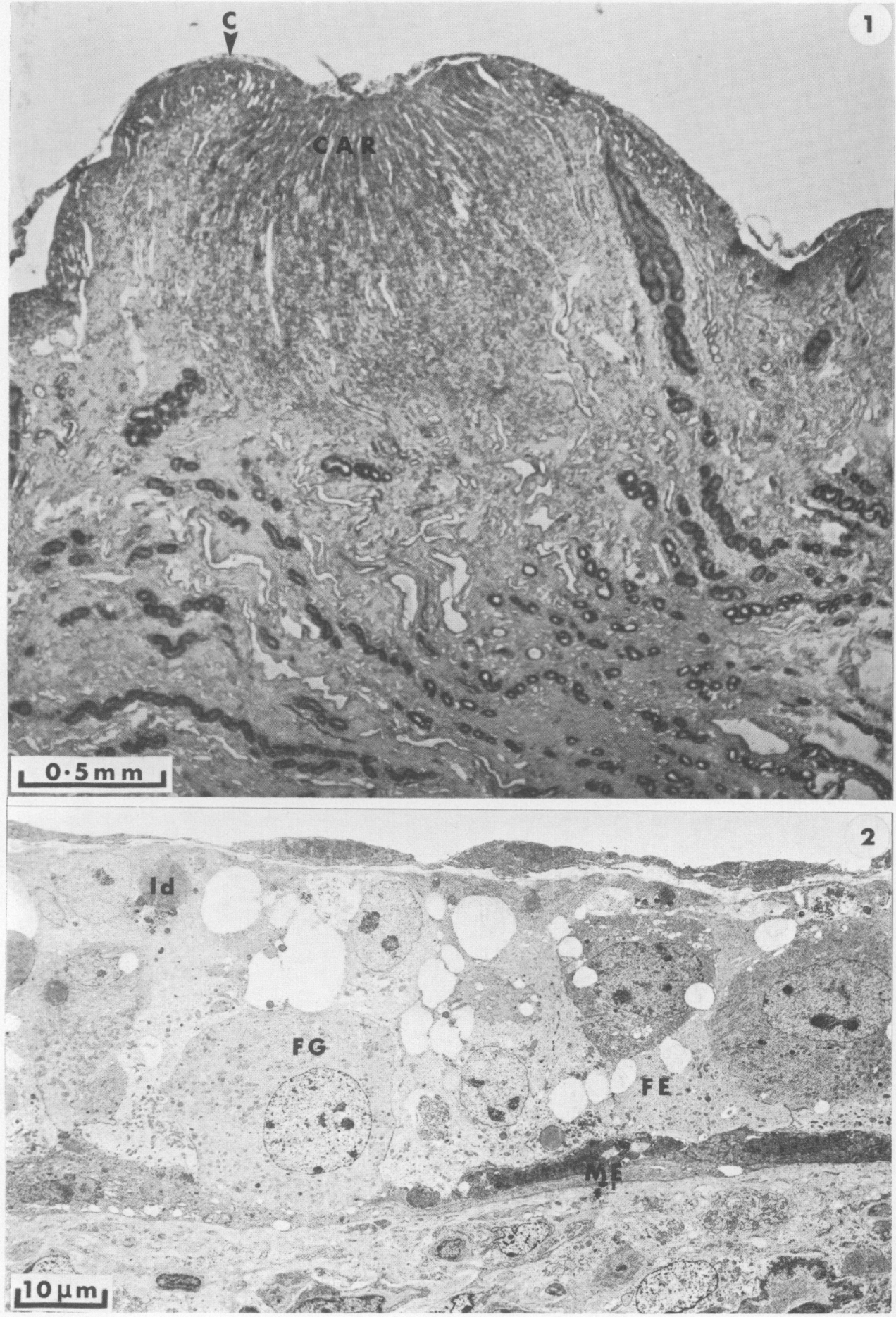

(Facing p. 98) 
PLATE 2
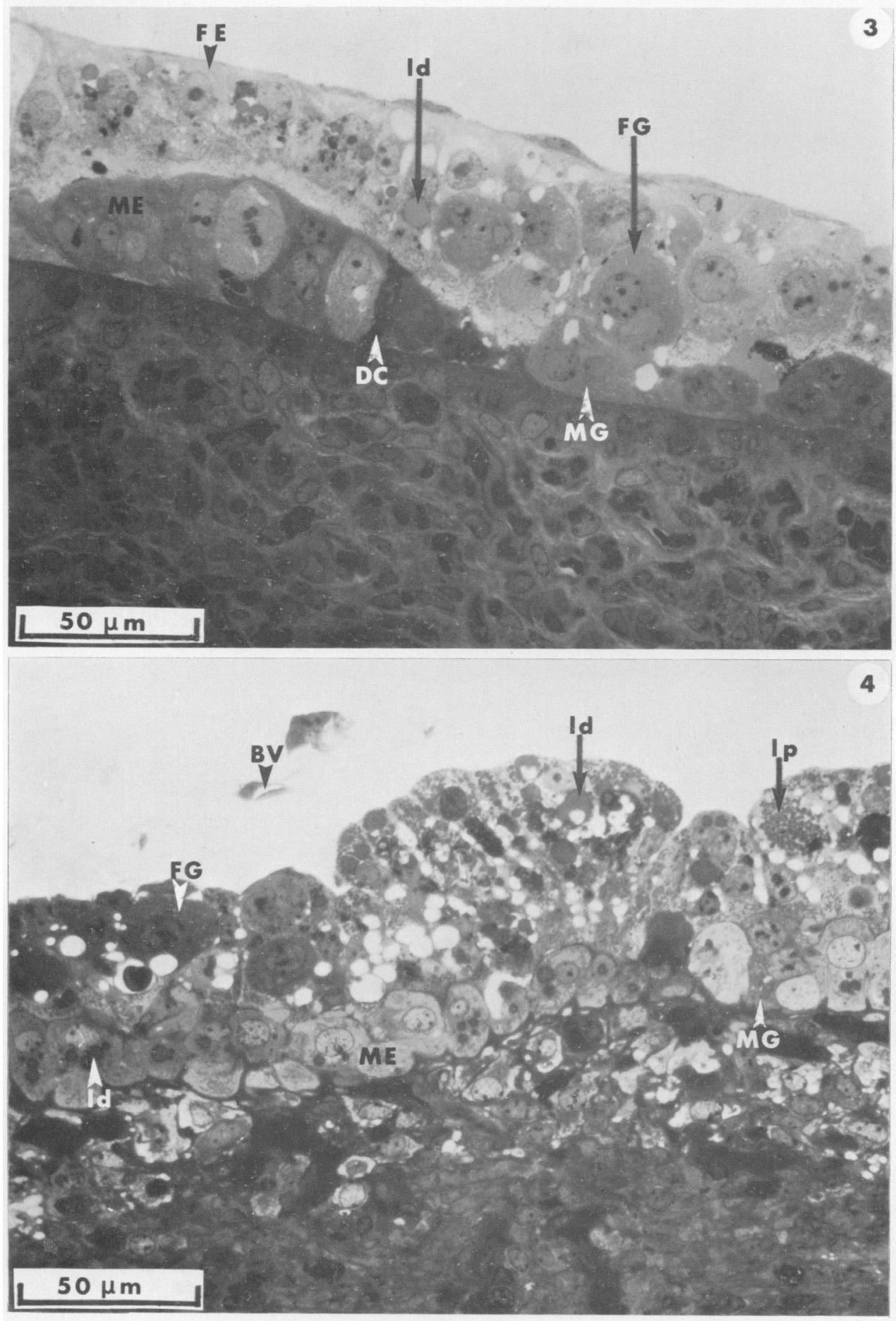


\section{PLATE 3}

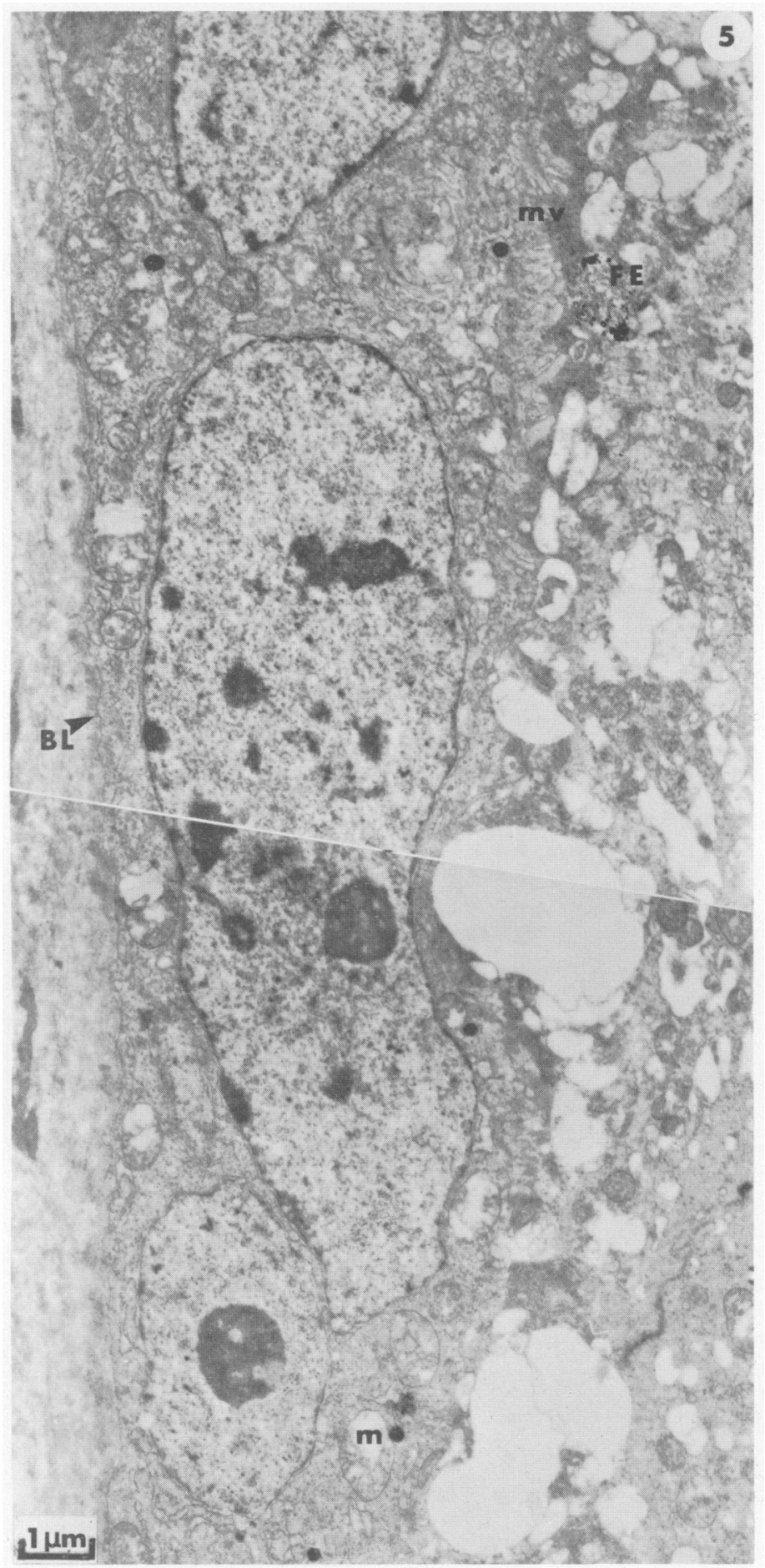


PLATE 4
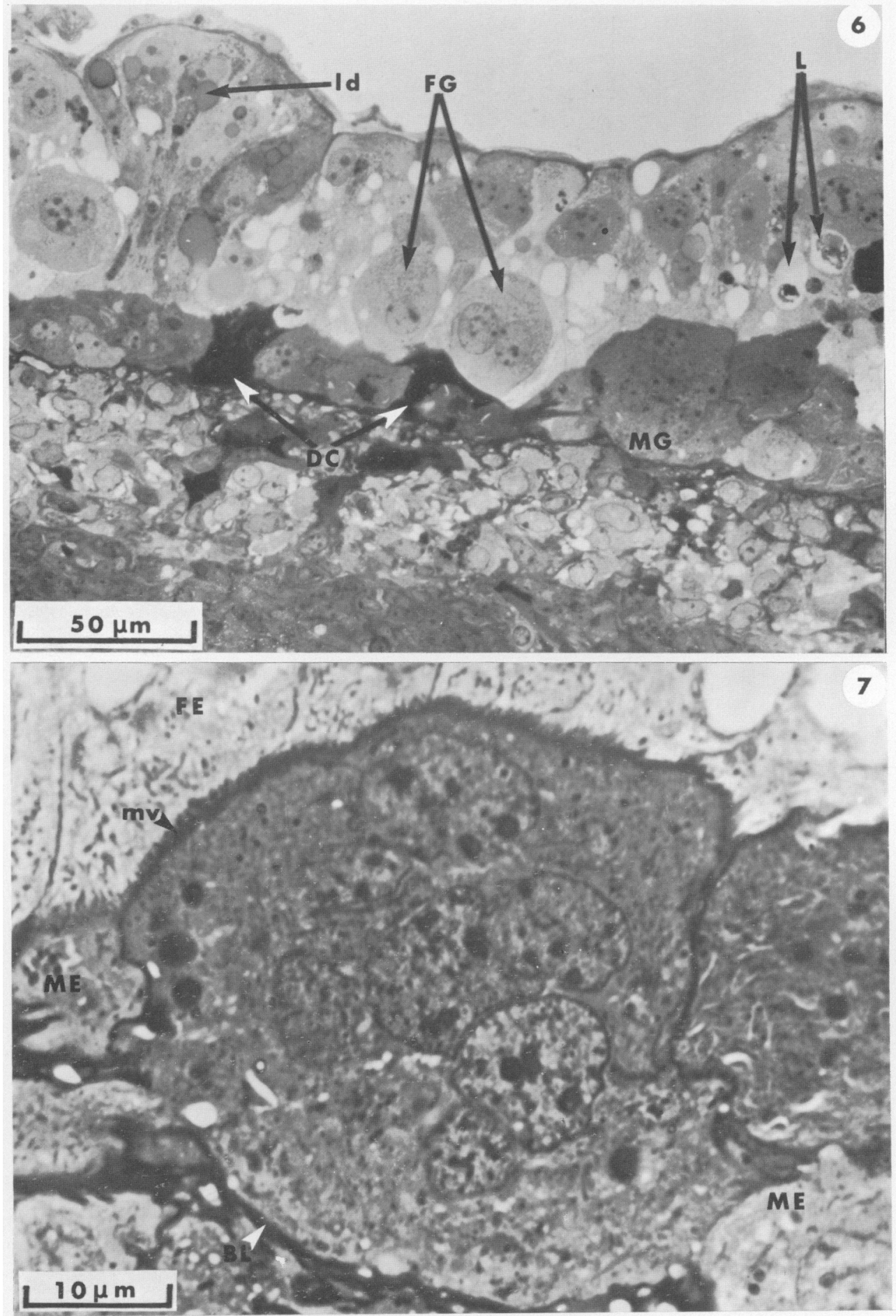


\section{PLATE 5}

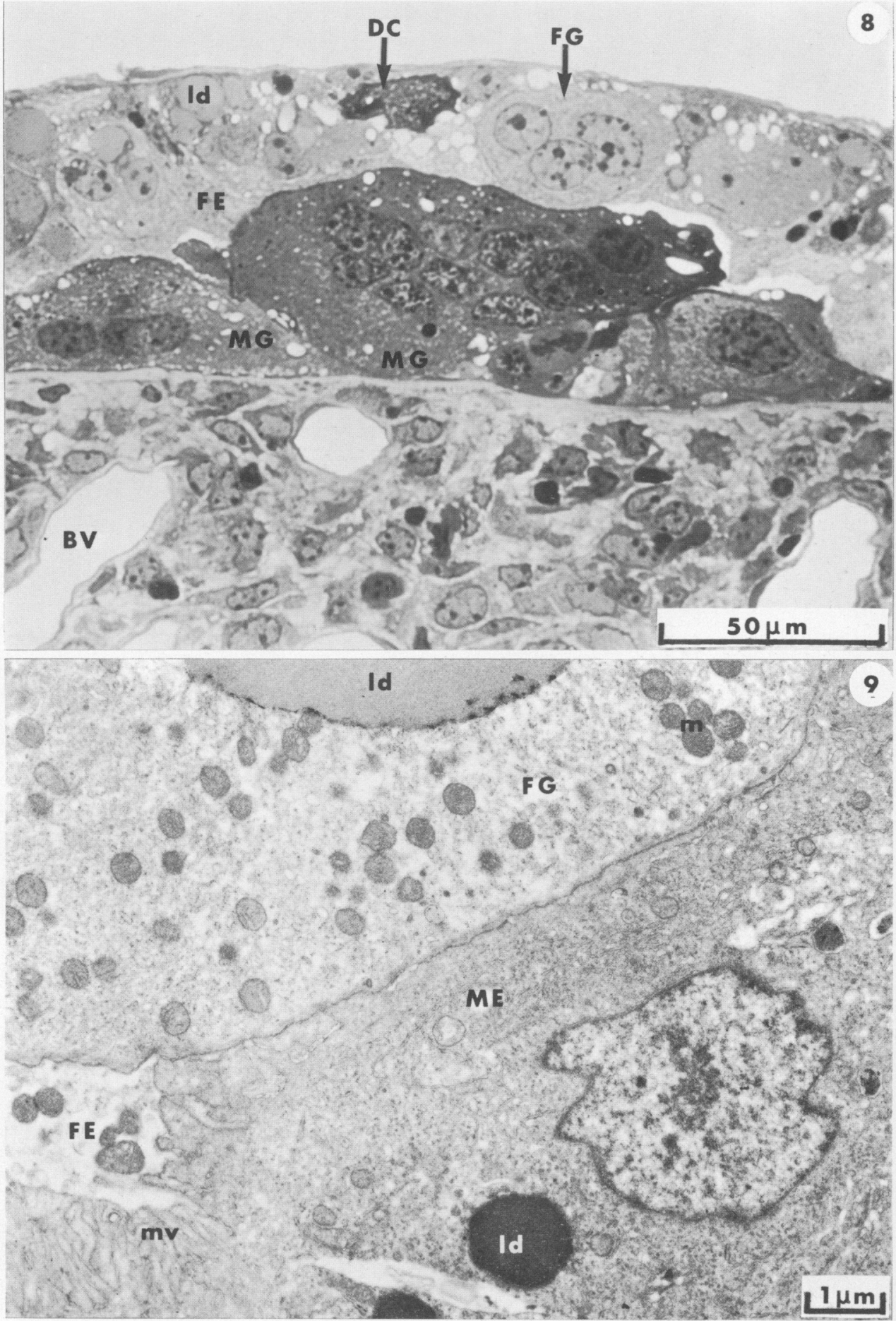


PLATE 6

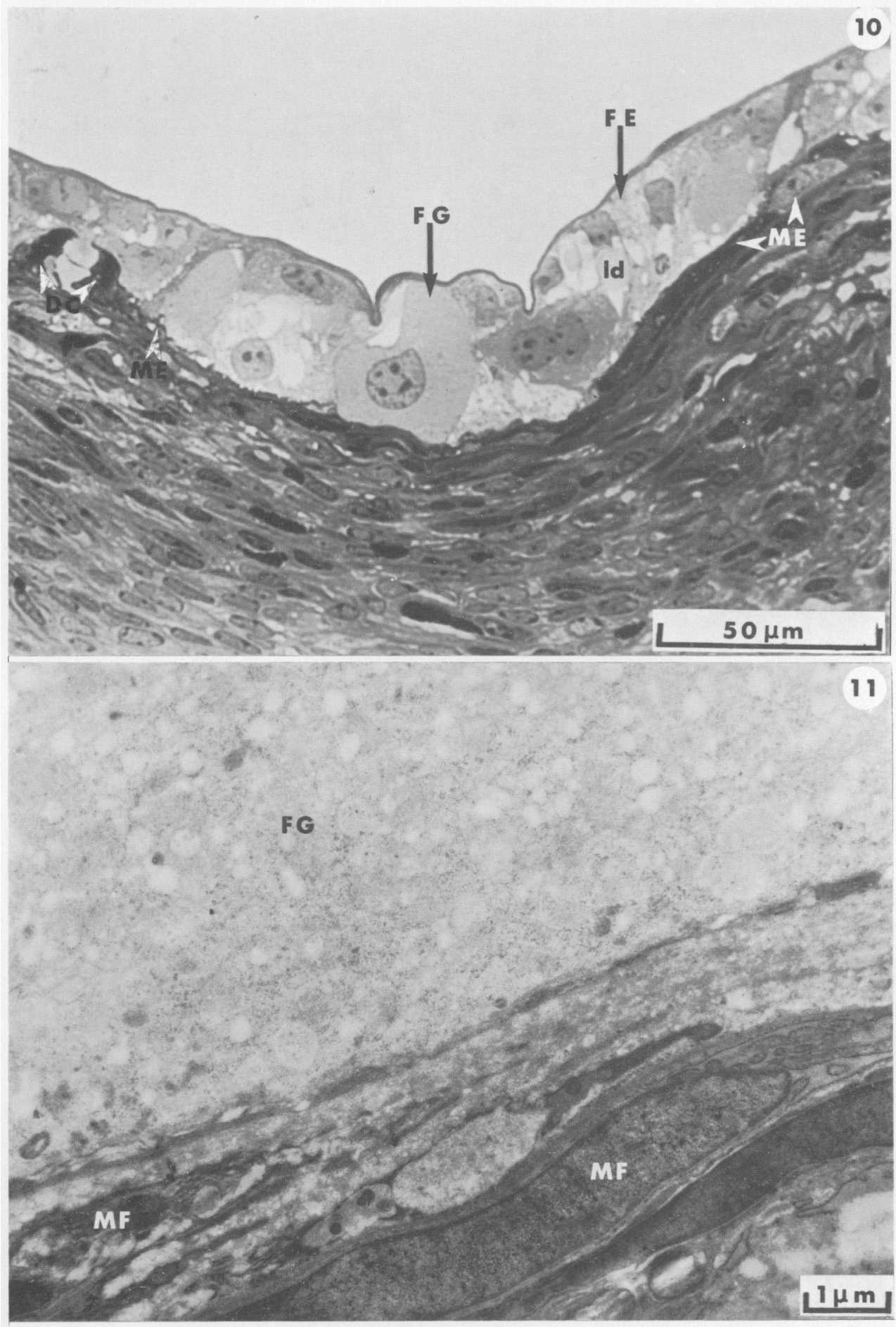


PLATE 7

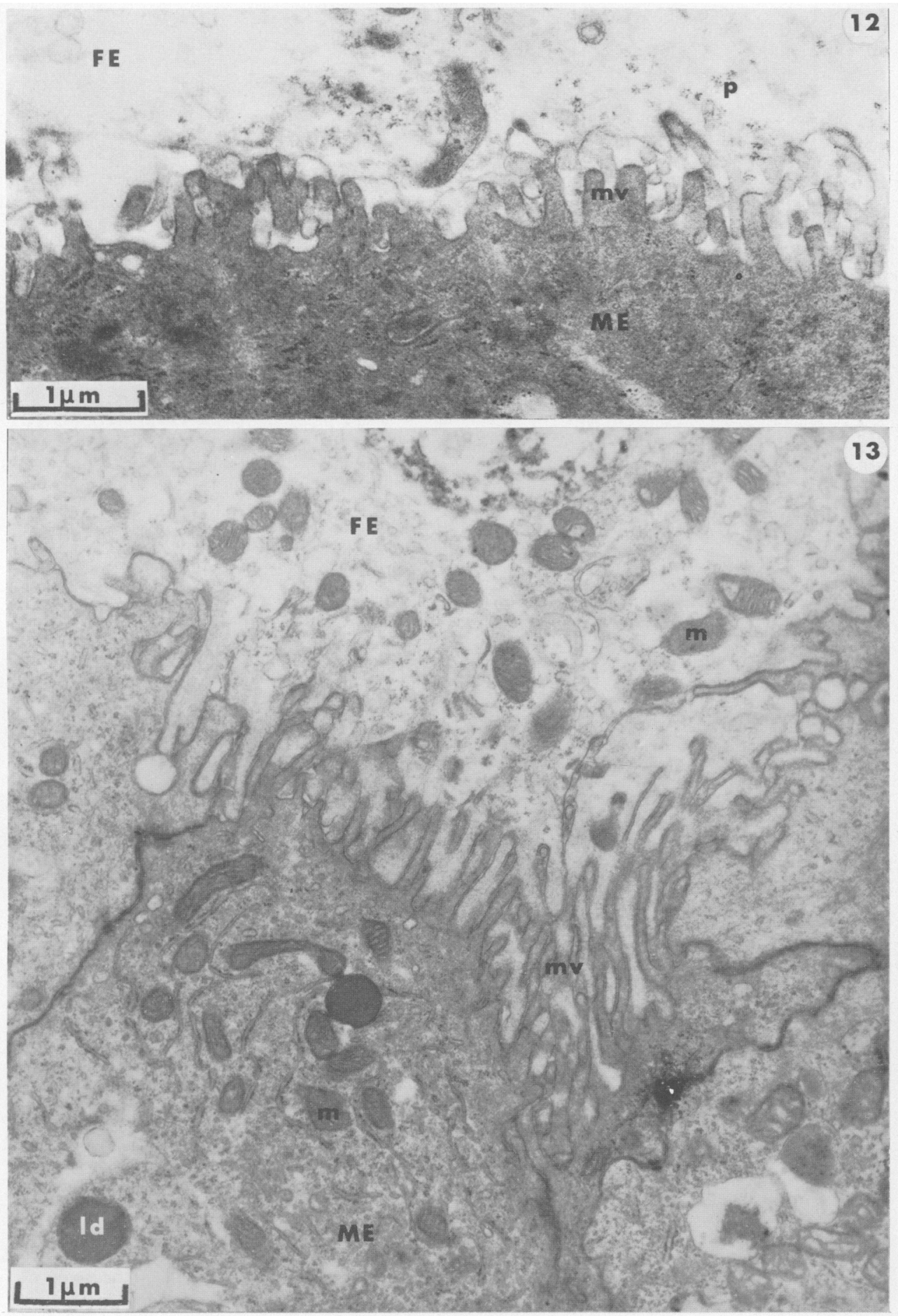


PLATE 8

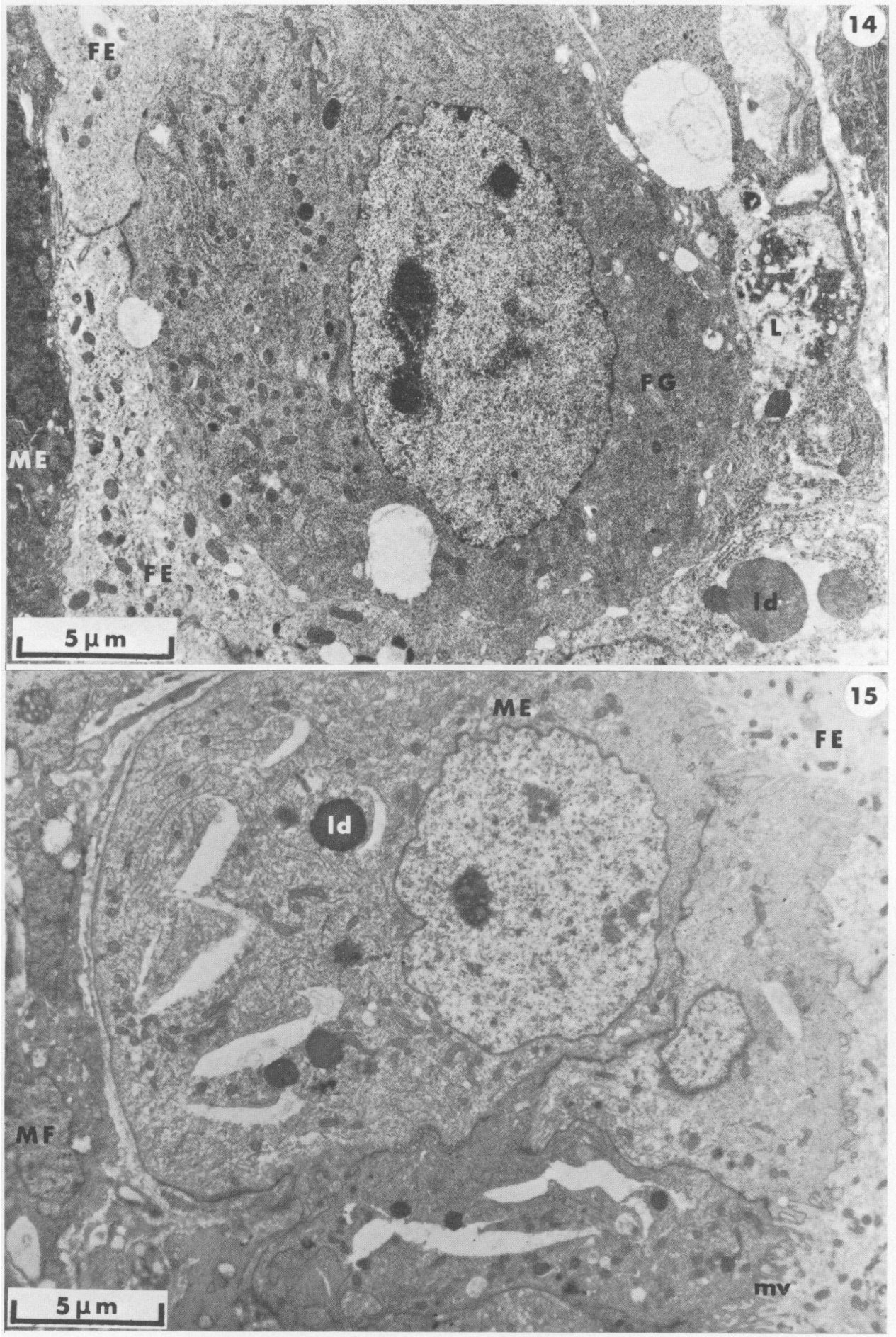


The regular, mononuclear, epithelial cells of the trophoblast exhibited round, lightly stained, randomly located nuclei. The cytoplasm of these cells contained polysomes and sparse endoplasmic reticulum throughout, with numerous apically located mitochondria. The trophoblast giant cells were common at all stages (Pl. 1, Fig. 2; Pl. 2, Figs. 3 and 4; Pl. 4, Fig. 6; Pl. 6, Fig. 10). In section, these cells contained single or multiple nuclei varying from round to slightly irregular in shape. The principal organelles exhibited by these cells were rough endoplasmic reticulum, discrete ribosomes and mitochondria (Pl. 8, Fig. 14). The number of small, circular, membrane-bound vesicles located in the basal regions of the trophoblast giant cells increased as gestation progressed, indicating development of secretory function. Several giant cells were observed in contact with the maternal component of the placenta (Pl. 1, Fig. 2; Pl. 2, Fig. 3; Pl. 4, Fig. 6; Pl. 6, Fig. 10) and this contact was confirmed by electron microscopy (P1. 1, Fig. 2; Pl. 5, Fig. 9). Although intimate contact was present, microvilli were never found on any surface of a trophoblast giant cell.

Vascularization of the trophoblast was first noted in specimens collected on Day 26.

\section{Discussion}

There is considerable controversy regarding the time when attachment of the trophoblast and endometrium is initiated during early bovine pregnancy. Winters, Green \& Comstock (1942) attempted to flush or dissect embryos from gravid uteri and, since they could remove only fragments of chorion on Day 13, assumed attachment had occurred before this. However, Betteridge, Mitchell, Eaglesome \& Randall (1976) flushed intact viable blastocysts from the uterine lumina of superovulated cows as late as Day 16 after oestrus. Drieux \& Thiery (1951) detected the presence of villous projections on the chorion, which entered the openings of the uterine glands by the 15 th day and thus would constitute a loose attachment. Drieux \& Thiery (1951) also mentioned that cotyledons appeared towards the 30th day. Marshall \& Halman (1945) claimed that the first attachment, occurring on the 17 th day, was by villous projections from the yolk sac which anchored the embryo to the wall of the uterus. This initial attachment was replaced by attachment through the chorion which occurred during the 4th or 5th week of gestation. Unfortunately, no conclusive evidence or description of methodology was presented in the reports of Drieux \& Thiéry (1951) and Marshall \& Halman (1945).

In the present study, examination of caruncles collected from the gravid horn near the embryo indicated that apposition and tenuous adhesion between the chorion and maternal epithelium were detectable at Day 20. The placentome was a discrete, recognizable structure in both gross and microscopic specimens at the earliest stages studied. The size of the placentomes and the intimacy of attachment had increased by Day 29 but no villi or crypts had formed.

Leiser (1975) established that the implantation process of the bovine embryo was not uniform. The apposition phase and actual start of implantation occurred by Day 18-19 in the region near the embryo. Apposition had spread $10-15 \mathrm{~cm}$ from the original site by Day 22 and adhesion was completed in the embryonic area. He concluded that implantation had extended over the entire uterine mucosa by Day 27 with the exception of the caruncles and small regions in the intercaruncular area. In contrast, the present study demonstrated that $1 \mathrm{~mm}$ cubes, with adhering chorion, could be removed from caruncles of the mid-portion of the gravid horn on Day 20 and that interdigitation of microvilli between maternal epithelium and trophoblast had occurred by Day 24 in almost all caruncles examined. This indicates that the implantation process, in addition to the development of adhesion and attachment of the trophoblast to the maternal epithelium in the intercaruncular region between Days 22 and 27 (Leiser, 1975), involves the simultaneous formation of definitive placentomes.

This paper is Animal Research Institute contribution No. 893. 


\section{References}

Betteridge, K.J., Mitchell, D., Eaglesome, M.D. \& Randall C.G.B. (1976) Embryo transfer in cattle 10-17 days after estrus. Proc. 8th Int. Congr. Anim. Reprod. \& A.I., Cracow, iii, 237-240.

Björkman, N.H. (1968) Fine structure of cryptal and trophoblastic giant cells in the bovine placentome. $J$. Ultrastruct. Res. 24, 249-258.

Drieux, H. \& Thiéry, G. (1951) La placentation chez les mammifères domestiques III. Placenta des bovidés. Rec. Mèd. Vét. 127, 5-25.

King, G.J., Atkinson, B.A. \& Robertson, H.A. (1979) Development of the bovine placentome during the second month of gestation. J. Reprod. Fert. 55, 173-180.
Leiser, R. (1975) Kontaktaufnahme zwischen trophoblast und uterusepithel während der frühen implantation beim rind. Anat. Histol. Embryol. 4, 63-86.

Marshall, F.H.A. \& Halman, E.T. (1945) Physiology of Farm Animals, 3rd edn, pp. 242-244. Cambridge University Press.

Spurr, A.R. (1969) A low viscosity epoxy resin embedding medium for electron microscopy. J. Ultrastruct. Res. 26, 31-43.

Winters, L.M., Green, W.W. \& Comstock, R.E. (1942) Prenatal development of the bovine. Tech. Bull. Minn. Agr. Exp. Stn. No. 151.

Received 27 September 1979 